\title{
Институт Омбудсмана в Азербайджанской Республике
}

Алиев Заур Гумбат огль"

В современный период права и свободы человека, их обеспечение и эффективная защита, а также позитивизация естественных прав человека, то есть их отражение в национальном законодательстве со стороны государства, выступают как важный фактор в развитии каждого государства и общества.

Права человека присущи природе человека, поэтому они носят естественный характер, принадлежат человеку с момента его рождения, и их уважение, соблюдение и защита являются важнейшим обязательством государства.

Наряду с отражением во внутренних законодательных актах, права и свободы человека также закреплены в универсальных и региональных международных документах. Некоторые из них, превращаясь в общепризнанные нормы, становятся правами, соблюдение которых носит обязательный характер (например, право на жизнь и т.д.).

Общепризнанные права и свободы человека отражены в ряде международных документов, таких как Всеобщая декларация прав человека, Международный пакт о гражданских и политических правах, Европейская конвенция по правам человека и т.д. Эти права принадлежат всем людям без какой-либо дискриминации. В современный период ни одно государство не может нарушить основные права и свободы человека, отраженные в вышеуказанных международных договорах, ссьлаясь на то, что не является их участником. Противоправные действия этих государств могут быть истолкованы как нарушение общепризнанных норм международного права (например, незаконное лишение жизни, пытки и т.д.).

Необходимо отметить, что впервые идея защиты прав человека на международном уровне нашла свое отражение в Уставе $\mathrm{OOH}$ - универсальной организации, созданной в целях обеспечения мира

\footnotetext{
- Алиев Заур Гумбат оглы - магистр права, член Российской ассоциации международного права, сотрудник аппарата Уполномоченного по правам человека (Омбудсмана) Азербайджанской Республики, государственный служащий первой степени.
} 
и безопасности и развития сотрудничества между государствами. «Поддержка и поощрение уважения к правам всех без исключения людей, независимо от расы, пола, языка или религиозной принадлежности» заявляется в Уставе как одна из основных целей ООН (ст. 1). «Единогласная поддержка уважения и соблюдения прав и свобод всех людей» (ст. 55) и осуществление в этих целях совместных с ООН и независимых мероприятий (ст. 56) было возложено как обязательство на все государства.

Однако, как видно, в Уставе не перечисляются конкретные права и свободы человека. Для устранения этого недостатка 10 декабря 1948 года на основании Резолюции 217 (III) Генеральной Ассамблеи ООН была принята Всеобщая декларация прав человека. В этом документе, состоящем из 30 статей, помимо гражданских и политических прав также закреплены ряд экономических, социальных и культурньх прав. Несмотря на отсутствие непосредственной юридической силы Декларации, ее основные положения нашли свое отражение в конституциях и других законодательных актах многих государств, а также в решениях национальных судов. Декларация сыграла важную роль в развитии международного права и прав человека. Основные принципы Декларации также нашли свое отражение в Конституции Азербайджана.

К концу прошлого столетия, после восстановления независимости, в нашей республике начали осуществляться правовые реформы в различных сферах государства и общественной жизни.

12 ноября 1995 года путем всенародного голосования был принят Основной закон страны. В этом документе, помимо отражения обших принципов права, азербайджанский народ закрепил обеспечение прав человека и гражданина как важнейшую цель государства. Положительным является то, что Конституция, впервые в истории государственного строительства, отразила естественный характер прав человека, так как согласно Конституции у каждого человека с момента рождения есть неприкосновенные и неотделимые права и свободы. В Конституции, наряду с заявлением о естественном характере прав человека, перечисляются основные права и свободы человека. III раздел Конституции полностью посвящен правам и свободам человека и гражданина.

Демократическо-правовые реформы в Азербайджане создали условия для достижения существенного прогресса в сфере защиты прав человека на основе общепринятых норм и принципов международно- 
го права. За этот период наша страна присоединилась к многочисленным международным конвенциям, более чем половина из которых прямо или косвенно касается основных прав и свобод человека.

25 января 2001 года Азербайджан стал полноправным членом Совета Европы-влиятельной региональной организации, главной целью которой является защита прав человека. Тем самым 25 декабря 2001 года Азербайджан присоединился к Европейской Конвенции «О защите прав и основных свобод человека» и принял обязательство усовершенствовать национальное законодательство в соответствии с этой Конвенцией и европейскими стандартами в области права.

Одним из важнейших этапов в реформах, проведенных Азербайджанской Республикой на пути к интеграции в европейское правовое пространство, было создание института Омбудсмана - эффективного правозащитного механизма в зашите прав и свобод человека.

Важность создания института Омбудсмана обуславливается рядом причин. В мировой практике институт Омбудсмана, наряду с правозащитной деятельностью, знакомится с реальными проблемами граждан, систематизируя и анализируя результаты практической деятельности, содействует усовершенствованию законодательства в целях защиты прав и свобод человека. Также Омбудсман наряду с рассмотрением жалоб проводит просветительскую работу в сфере прав и свобод человека среди различных слоев населения, создает условия для укрепления единства в обществе и, поднимая вопросы о должностных злоупотреблениях, выступает гарантом соблюдения дозволенных рамок со стороны государственных органов и должностных лиц.

Важным элементом, создаюшим Омбудсману условия для более эффективной защиты прав человека и строительства правового государства, является то, что граждане имеют возможность обращаться напрямую к Уполномоченному. То есть нет необходимости в посредниках: ни в адвокате, ни в законном представителе.

Также, поднимая вопросы отношения между гражданами и государством на более высокий уровень, Омбудсман дает импульс появлению двустороннего доверия, укрепляет веру в государственность.

Будучи независимой структурой, институт Омбудсмана является дополнительным государственным механизмом для внесудебной защиты прав и свобод человека.

Главным преимуществом института Омбудсмана является то, что этот институт имеет общественный и демократический характер, 
независим и неприкосновенен. Омбудсман имеет возможность оказывать неформальную и неотложную помощь, искоренять бюрократические препятствия, коррупцию и совершенствовать государственное управление, обеспечивать прозрачность, а также то, что все слои населения имеют к нему полный доступ. Недаром в правовых системах развитых стран мира институт Омбудсмана считается важным механизмом для защиты прав и свобод человека и укрепления законной деятельности государственных органов.

Сегодня, как и во многих развитых демократических странах, в Азербайджане функционирует учреждение Омбудсмана, являющееся одним из важнейших институтов правового государства в современном обществе. Учреждение и плодотворная деятельность данного института в Азербайджане наглядно свидетельствует о том, что наша республика строит правовое государство и гражданское общество. Принятие 28 декабря 2001 года Конституционного Закона «Об Уполномоченном по правам человека (Омбудсмане) Азербайджанской Республики» является составной частью правовых реформ в сфере защиты прав человека в нашей стране. В то же время для создания и функщионирования института Омбудсмана была создана материальная и юридическая база.

2 июля 2002 года Парламент страны избрал первого Омбудсмана Азербайджана.

2 июля 2002 года был принят Закон Азербайджанской Республики об изменениях и дополнениях в некоторые законодательные акты в связи с применением Конституционного Закона «Об Уполномоченном по правам человека (Омбудсмане)».

Данным Законом, в целях обеспечения деятельности Омбудсмана, были внесены изменения и дополнения в следующие законодательные акты: «Закон о чрезвычайном положении», «Закон о политических партиях», «Закон об основах призыва на воинскую службу», «Закон о пенсионном обеспечении граждан», «Закон о воинской службе», «Закон о военном положении», «Закон о въезде в страну, выезде из страны и паспортах», «Закон о порядке рассмотрения обращений граждан», «Закон о Конституционном Суде», «Закон о дорожном движении», «Таможенный кодекс», «Кодекс об административных правонарушениях», «Уголовно-процессуальный кодекс), «Кодекс об исполнении наказаний».

24 августа 2002 года в результате всенародного голосования (референдума) в Конституцин были отражены положения о выцвижении кан- 
дидатуры Уполномоченного (ст. 109, п. 14), избрании (ст. 95), праве на обрашение в Конституционный Суд с целью определения соответствия нормативно-правовых актов Конституции.

Уже через три месяца после избрания, 28 октября 2002 года, Омбудсман приступил к приему заявителей и рассмотрению жалоб. По сравнению с другими странами, в Азербайджане Омбудсман начал свою деятельность через короткий срок после избрания. Это результат внимания нашего государства к своевременному выполнению обязательств в сфере зашиты прав и свобод человека.

Учитывая то, что учреждение Омбудсмана - новое явление для Азербайджана, что общество нуждается в получении информации об Омбудсмане, а также важность построения сотрудничества с другими государственными органами, в сентябре-октябре 2002 года в рамках проекта Программы развития $\mathrm{OOH}$ «Создание Омбудсмана и увеличение потенциальных возможностей Парламента Азербайджана» при участии Верховного Комиссара Совета Европы по правам человека был проведен ряд семинаров на темы: «Создание учреждения Омбудсмана в Азербайджане и его роль в развитии демократии», «Правила рассмотрения жалоб со стороны Уполпомоченного», «Деятельность Уполномоченного по правам человека в защите прав заключенных» при участии представителей Совета Европы, ОБСЕ, ООН и ряда других международных организаций, «Применение Европейской Конвенции по правам человека со стороны учреждения Омбудсмана» при участии Омбудсмана Косово и Второго Директората по правам человека Секретариата Совета Европы.

В этих семинарах также участвовали депутаты Милли Меджлиса (Парламента), представители исполнительного аппарата Президента, аппарата Милли Меджлиса, Конституционного Суда, Верховного Суда, Апелияционного Суда, прокуратуры, Министерства внутренних дел, Министерства юстиции, других государственных органов, а также представители ряда НПО и СМИ.

Проведенные мероприятия создали благоприятную почву для распространения информации в обществе об Омбудсмане, просвещении населения об его обязанностях, полномочиях и роли в обществе, создания сотрудничества с государственными органами.

С момента начала деятельности Омбудсман для претворения в жизнь полномочий, предоставленных Конституцией, осушествил ряд мероприятий в соответствующих направлениях. 
В ст. 1.1 Конституционного Закона об Уполномоченном по правам человека (Омбудсмане) указывается, что «должность Уполномоченного по правам человека Азербайджанской Республики учреждается для восстановления прав и свобод человека, определенных Конституцией Азербайджанской Республики, международными договорами, участником которых является Азербайджанская Республика, и нарушенных государственными органами, органами местного самоуправления и должностными лицами». Закон предоставил Омбудсману широкие полномочия в сфере строительства правового государства и защиты важнейших принципов государства.

28 октября 2003 года исполнился год с начала деятельности Омбудсмана, и в соответствии со ст. 14 Конституционного Закона Уполномоченный предоставил Президенту Азербайджанской Республики и Милли Меджлису свой первый годовой доклад.

В первом годовом докладе нашли отражение система защиты прав человека, проведенные правовые реформы, основные требования международных договоров, к которым присоединился Азербайджан, во внутреннем законодательстве, выполнение обязательст, взятьх при вступлении в Совет Европы, история учреждения Омбудсмана, его роль в правовом государстве, результаты деятельности Омбудсмана по восстановлению прав человека, сотрудничество Уполномоченного с государственными органами в сфере защиты прав человека, обеспечение прав человека, правовое просвещение населения, создание в стране среды уважения к правам человека, сушествуюшие трудности в сфере обеспечения прав человека, а также обобщенные предложения Омбудсмана в сфере эффективного обеспечения прав человека и решения проблем определенных групп населения.

Во втором годовом докладе «О ситуации с обеспечением и защитой прав человека в Азербайджане» нашли отражение деятельность Омбудсмана в сфере защиты прав и свобод человека, а также деятельность, направленная на защиту гражданских и политических прав права на свободу и личную неприкосновенность; права на защиту чести и достоинства; свободы слова, мысли, получения информации; свободы совести; права выбора; права на обращение; права на объединение; права судебного обеспечения; права на получение правовой помощи, а также экономических, социальных и культурных прав права на труд, права на работу в безопасных условиях, права на социальное обеспечение, права на жизнь в безопасной окружающей среде, 
права на защиту здоровья, права на образование, права на жилище, права на свободное предпринимательство и иных прав, отраженных во внутреннем законодательстве и в международных договорах, участником которых является Азербайджан. Также было уделено внимание проблемам отдельных категорий населения, особенно таких, как беженцы и вынужденные переселенцы, заключенные, военнослужашие и др. В докладе нашла отражение деятельность Омбудсмана в сферах правового просвещения, научно-аналитической деятельности, сотрудничества со СМИ и общественностью, международных отношений. В итоговой части доклада бьли отмечены обшие мысли, мнения и предложения, связанные с обеспечением прав человека.

В период деятельности Омбудсмана был проведен ряд мероприятий, направленных на решение различных проблем населения.

Для достижения эффективного решения проблем, выявленных в результате анализа поступивших жалоб, были налажены связи с соответствующими государственными органами. Для привлечения внимания государственных органов к проблемам населения был подготовлен пакет соответствующих предложений.

В соответствии со ст. 1.5 Закона об Уполномоченном по правам человека Азербайджанской Республики Уполномоченный в целях обеспечения прав и свобод человека может давать рекомендации в Милли Меджлис (Парламент) о принятии законов или их пересмотре. Используя свои полномочия, Омбудсман направил в Милпи Меджпис (Парламент) ряд предложений в целях обеспечения прав человека.

Среди предложений Омбудсмана, связанных с усовершенствованием законодательства, нашли отражение вопросы о гражданских и политических правах.

Был внесен ряд предложений, таких как: определение правил подачи кассационной жалобы в Кодексе «Об административных правонарушениях» с целью гарантирования права на подачу жалобы в Верховный Суд на решения нижестоящих судов по делам об административных проступках; внесение сушественных изменений в соответствии с законом «Об адвокатах и адвокатской деятельности» для усовершенствования института адвокатства; внесение изменений и дополнений в закон «Об исполнении судебных решений» и других законодательных актов в целях расширения функций суда, усиления контроля за исполнением судебных решений, сокращения сроков, указанных в законодательстве для регистрации юридических лиц и внесения в госу- 
дарственный реестр; подготовка и принятие законодательных актов для предотвращения торговли людьми и т.д.

Среди предложений Омбудсмана, связанных с усовершенствованием законодательства, важное место занимают вопросы обеспечения социальных и экономических прав. В перечень этих вопросов вошли определение административной ответственности за неуплату или задержку в уплате долга, определенного трудовым контрактом, со стороны работодателей; соответствие суммы пенсий граждан, ушедших на пенсию в различное время, на основании проекта «Закона о пенсии»; предоставление пожилым гражданам специальных финансовых гарантий (страховка жизни и т.д.); определение минимального размера пенсий, их соответствие минимальным жизненным стандартам и т.д.

Уполномоченный также предоставил в Парламент предложения связанные с подготовкой законодательного акта о правах женщин, гендерном равенстве и насилии в семье.

Как известно, в результате агрессии Армении против Азербайджана 20\% наших территорий было оккупировано, более миллиона наших соотечественников стали беженцами и вынужденными переселенцами. Защита прав беженцев и вынужденных переселенцев является одним из приоритетных направлений в деятельности Уполномоченного. Для более эффективной защиты их прав Уполномоченный направил в кабинет министров предложения, связанные с обеспечением работой беженцев и вынужденных переселенцев в местах их компактного проживания, подготовкой и претворением в жизнь плана действий в целях привлечения беженцев и вынужденных переселенцев к мелкому предпринимательству и сельскохозяйственным работам, ускорением их переселения из палаточных лагерей и вагонов, освобождением членов семей вынужденных переселенцев и жертв войны, обучающихся в высших и средних специализированных учебных заведениях от оплаты.

Необходимо отметить, что 1 июля 2004 года Президент своим указом утвердил «Государственную Программу по улучшению условий жизни и занятости беженцев и вынужденных переселенцев». В результате этого был решен ряд важных проблем, в том числе проблема занятости.

Начиная с июля 2004 года, в целях более оперативного реагирования на факты нарушения прав человека и обеспечения их защиты, 
Омбудсман в сотрудничестве с Бакинским офисом ОБСЕ начал осуществлять проект под названием «Помощь Уполномоченному по правам человека в расследовании случаев нарушения прав человека в изоляторах и местах временного содержания и обеспечении быстрого ответа на жалобы». Для обеспечения исполнения проекта из сотрудников аппарата Омбудсмана была создана «группа быстрого реагирования». Для членов данной группы были проведены тренинги, обсуждены их обязанности, а также проведены обсуждения, связанные с «Законом о полиции», «Европейской Конвенцией о правах человека», «Конвенцией против пыток и других жестоких, бесчеловечных или унижающих достоинство видов обращения и наказания».

Совместно со специалистами Министерства внутренних дел для сотрудников полиции в различных городах и районах были проведены семинары-консультация, касающиеся роли полиции в защите прав человека в соответствии с внутренним законодательством и международными конвенциями.

На основания графика, подтвержденного Уполномоченным, «группа быстрого реагирования» провела осмотр более чем в 150 полицейских управлениях, участках, изоляторах и местах временного содержания. В то же время была проверена вся информация, связанная с нарушениями прав человека, которая поступала на мобильный телефон, функционирующий 24 часа, проведены осмотры на местах, приняты необходимые меры. Во время осмотров не были выявлены случаи пыток, но были стучаи содержания задержанных сверх срока, предусмотренного законом, и нарушения в ходе документирования. В связи с этими нарушениями в Министерство внутренних дел периодически представлялась соответствуюшая информация.

Омбудсман, используя свои функции посредника (медиатора), предпринял ряд мер в целях ликвидации таких негативных явлений, как торговля людьми и коррупция, а также в целях объединения ресурсов соответствуюших государственных органов и гражданского общества.

Коррупџия является одним из основньх источников нарушения прав человека, она приводит к потере доверия населения к государственным органам, и борьба с этим опасным для всего общества преступлением является приоритетным направлением в политике государства. Для борьбы с коррупцией была создана важная нормативно-правовая база.

В целях борьбы с коррупцией Омбудсман организовал ряд «круглых столов», выступил с рядом предложений во время подготовки про- 
екта «Государственной Программы по борьбе с коррупцией (20042005)». Кроме того, представитель Омбудсмана является членом «Комиссии по борьбе против коррупии» при кабинете министров.

В целях борьбы с торговлей людьми Омбудсман в основном проводил просветительскую работу на основании «Национального плана действий против торговли людьми». В будущем Омбудсман планирует усиление деятельности в этом направлении.

Омбудсман сотрудничает с государственными органами, а также уделяет большое внимание плодотворному сотрудничеству с НПО и общественностью.

Для более полезного и целенаправленного сотрудничества в апреле 2003 года при Омбудсмане был создан Совет независимых экспертов. В Совете, помимо представителей государственных органов, также представлена общественность. Деятельность Совета направлена на анализ состояния прав человека, подготовку предложений по усовершенствованию законодательства, проведение совместных мероприятий и т.д.

Важным элементом деятельности Омбудсмана является международное сотрудничество. С первых дней деятельности аппарата Омбудсмана его сотрудники в целях изучения международного опыта участвовали во многих международных мероприятиях как внутри страны, так и за ее пределами.

Для эффективной зашиты прав человека и недопущения их нарушения, а также для решения проблем различных слоев населения Омбудсман тесно сотрудничает с такими органами ООН, как Детский фонд, Верховный Комиссариат по делам беженщев, Верховный Комиссариат по правам человека, ЮНЕСКО, а также с региональными международными организациями, такими как Европейский Сою3, Совет Европы ит.д.

В период своей деятельности Омбудсман и его сотрудники приняли участие примерно в 70 международных мероприятиях.

Помимо мероприятий, проведенных за границей с целью получения опыта и развития отношений с различными международными организациями, в городе Баку Омбудсман организовал три важных международньг мероприятия.

Первым из этих мероприятий была 1-я Международная конференция Омбудсманов в Баку, проведенная 9-13 июня 2003 года совместно с молодежной организацией «Надежное будущее». 
Второе мероприятие, Международный круглый стол Омбудсманов, было проведено 20-21 ноября 2003 года в сотрудничестве с Программой Развития ООН.

И наконец, 29-30 ноября 2004 года по инициативе Омбудсмана Азербайджанской Республики и при поддержке ЮНЕСКО, в связи с десятилетием просвещения по правам человека $\mathrm{OOH}$, состоялась 3-я Международная конференция Омбудсманов на тему «Роль правового просвешения и гражданского общества в развитии демократизации».

За этот период по инициативе Уполномоченного был подписан ряд договоров о сотрудничестве с Омбудсманами различных стран: Украины, Грузии, Узбекистана, Российской Федерации, а также ее субъектов (Московской, Свердловской, Саратовской областей, Республики Татарстан).

В целом первые итоги деятельности Уполномоченного отражают зародившуюся необходимость страны в этом учреждении, которое за короткое время завоевало популярность среди населения, нуждающегося в построении правового государства и гражданского общества, успешную разработку плодотворных механизмов сотрудничества с государством, в том числе с правоохранительными органами, а также органами местного самоуправления, международными и национальными неправительственными организациями, средствами массовой информации.

За период своей деятельности аппарат Омбудсмана провел определенные мероприятия в разрешении существующих проблем и тем самым завоевал доверие среди населения.

Из этого видно, что в своей деятельности Омбудсман, осуществляя правозащитную деятельность, ближе ознакомился с проблемами населения, исследовал причины возникновения этих проблем и выдвинул определенные предложения для их разрешения.

Таким образом, на пути демократических реформ и построения правового государства Уполномоченный по правам человека Азербайджанской Республики наряду с иными правозашитными государственными механизмами выступает как основной гарант защиты прав человека. 